\title{
The Co-Creation of a Retail Innovation: Shoppers and the Early
}

\section{Supermarket in Britain.}

\author{
Andrew Alexander ${ }^{\mathrm{a}}$, Dawn Nell ${ }^{\mathrm{b}}$, Adrian R. Bailey ${ }^{\mathrm{c}}$, Gareth Shaw ${ }^{\mathrm{c}}$ \\ ${ }^{a}$ School of Management, University of Surrey, Guildford, Surrey, GU2 7XH UK \\ Email: A.Alexander @ surrey.ac.uk \\ ${ }^{\mathrm{b}}$ School of Management, University of Surrey, Guildford, Surrey, GU2 7XH UK \\ ${ }^{\mathrm{c} B u s i n e s s ~ S c h o o l, ~ U n i v e r s i t y ~ o f ~ E x e t e r, ~ E x e t e r ~ E X 4 ~ 4 P U, ~ U K ~}$
}

This is an author copy of a paper published in Enterprise \& Society Vol. 10 (3), 529-558

(2009). As such its format may differ from the final version published in the journal.

Figure 1 is provided at the end of the paper.

\section{INTRODUCTION}

The supermarket is an important innovation that transformed retailing in post-war Britain. ${ }^{1}$ However, detailed explorations of shoppers' reactions toward, and involvement in, the changing service encounters occurring in these new retail formats are generally lacking. This is a significant shortcoming because shoppers had to negotiate fundamental changes to their interactions with the physical environment of the store, the retail staff, other customers, and the products for sale. ${ }^{2}$

In this paper we begin to fill this gap in understanding through an analysis of the attitudes and behaviours of those who shopped at the early supermarkets (up to about 1975). We do so through the conceptual lens of co-creation, drawing upon literatures from business history, 
the social sciences, and marketing that share a concern with the role of consumers, or users, in innovation. ${ }^{3}$ As we discuss below, retailing provides a compelling case for analysis of cocreation thanks to its role in integrating the inputs of a network of agents including the shopper. ${ }^{4}$ Our evaluation includes matters relating to both the physical and mental tasks of shopping, including requisite learning and skills development. It is also encompasses a consideration of the experiences shoppers could undergo in the supermarket and that led to feelings and emotions such as satisfaction or dissatisfaction, and, more occasionally, fun, and excitement. More widely, our study complements attempts within the literature on consumption to break down the binary oppositions that have been constructed not only around production and consumption but also around the home and shop, and more generally the public and private spheres. ${ }^{5}$

Whilst our focus in this paper is upon co-creation resulting from shoppers' adoption we remain mindful of the influences of resistance and non-adoption on the innovation process. ${ }^{6}$ We also acknowledge that shoppers form only part of a wider network of agents, including product manufacturers and marketers, who were actively involved with retailers in the development of the supermarket innovation. ${ }^{7}$

In contrast to most existing studies of the history of the British supermarket, this paper forefronts shoppers' own perceptions and reflections on the new shopping encounters in which they participated. ${ }^{8}$ This is important for, valuable as they are, contemporaneous market research data reflect the wants, needs and desires of the client. ${ }^{9}$ The shopper data we present are derived from a new collection of oral histories gathered as part of a wider UK Arts \& 
Humanities Research Council funded project designed to enhance understanding of consumers' reactions toward the post-war supermarket. ${ }^{10}$

The remainder of the paper is structured into three main sections. In the next section we explore the literature on co-creation and assess its significance to our understanding of the activities of the shopper in the new supermarkets. In the second section we present an overview of the development of the supermarket in post-war Britain before outlining our methodology. In the final section we present the findings of our analysis of these oral histories in support of our evaluation of shoppers' roles in the co-creation of the supermarket innovation, and discuss their implications.

\section{THE SUPERMARKET AS INNOVATION: PERSPECTIVES ON THE INPUT OF THE CONSUMER}

The significance of the consumer to the co-creation of innovations such as the supermarket is illustrated in literatures drawn from a variety of perspectives and between which there remains only partial cross-fertilisation of conceptual and empirical material. ${ }^{11}$

Economic analyses of the retail sector highlight the importance of the shopper in relation to the switching of distribution costs between them and the retailer. ${ }^{12}$ This is arguably nowhere more evident than in relation to the rapid diffusion of the supermarket, in which self-service organisation saw shoppers replace the retailer in undertaking much of the work in handling and transporting goods through the store and to the home. ${ }^{13}$ Retailers promised supermarket shoppers various forms of possible recompense for the additional costs they incurred in 
undertaking the new form of shopping including reduced time spent in queues, a reduction in the overall work of food shopping as a result of the opportunities for one-stop shopping, enhanced freedom of choice through the personal selection of goods and, eventually, price reductions.

The potential of a wider consideration of the shopper's role in the supermarket innovation process can be discerned from research in the fields of business history, the history of technology, and social studies of science. ${ }^{14}$ This reveals how the capacity and willingness, or need, of consumers to commit to, and invest in, an innovation constitutes part of the context which determines its success or failure. In doing so it moves us beyond a passive interpretation of the role of consumers. It also highlights how decisions on use are often embedded in a myriad of social relations. ${ }^{15}$ Oudshoorn and Pinch's edited volume How Users Matter is concerned with understanding how users of innovations 'consume, modify, domesticate, design, reconfigure, and resist technologies' and promotes use of the term 'coconstruction' to highlight this dynamic in technological innovation. ${ }^{16}$ Whilst much of the work focuses on non-historical subject matter, its potential to stimulate conceptual and empirical work in business history has been recognised. ${ }^{17}$

Research on innovation in the service industries also analyses the role of consumers in the innovation process, exploring the significance of adding customer know-how to the formalisation of innovation in service-based relationships. ${ }^{18}$ In their study of innovation in services, Gallouj and Weinstein explain that 'the system...through which the consumer makes direct use of his knowledge and competences, represents in particular the various ways in which the client himself is "put to work" within the service firm. ${ }^{19}$ Recent attempts to 
promote a 'service-dominant logic' (S-D logic) in marketing are particularly significant in that they offer a more comprehensive framework for analysing the role of the customer. ${ }^{20} \mathrm{~S}$ D logic represents an attempt to reformulate marketing thought and practise. Its primary relevance to this study is the enhanced significance that it affords the customer through its assertion that "value is always co-created with and determined by the customer. ${ }^{21} \mathrm{~S}-\mathrm{D}$ logic contends that the application of skills and knowledge (so-called "operant resources") is the fundamental basis of exchange, that is to say exchange revolves around service not goods. Organisations, households and individuals act as resource integrators. Similar to aforementioned literatures, S-D logic identifies the role of the customer in co-producing the core offering. However, it contends that this co-production activity is subordinate to the customer's role in value creation; there is no value until an offering is consumed. ${ }^{22}$

The centrality of the consumer to the co-creation of value gives significance to attempts to identify those factors that determine their willingness and ability to co-create and the risks attendant in such activity. ${ }^{23}$ It has also led to efforts to extend the original propositions of S-D logic to more comprehensively acknowledge the contextual, experiential, and meaning-laden nature of value through consumption. ${ }^{24}$ Through such attempts S-D logic begins to connect with a far wider body of work concerned with consumption within both marketing itself and in the humanities and social sciences. ${ }^{25}$

We argue that existing references to the early supermarket as a prototypical example of customer co-creation give undue emphasis to the obvious alteration in the pattern of physical work. ${ }^{26}$ More attention needs to be given both to the development of shopper know-how and competences that accompanied such alterations, and to the wider experiences that surrounded 
shoppers' engagement with the supermarket innovation. We illustrate the significance of these two themes in the remainder of this part of the paper.

Shopper know-how is typically tacit in nature and comes through multiple interactions with the retail environment. In the case of the supermarket, new knowledge was essential because of the altered nature of shopper-retailer collaboration. Its importance would become magnified as retailers opened larger supermarket outlets in which shoppers were faced with not only a new physical selling environment, but also new modes of interaction with staff, other customers, and with an increasingly broad and deep range of products and services. Hence, whilst food shopping has been portrayed as a typically unreflective activity, ${ }^{27}$ in the switch to supermarket retailing it had the potential to become otherwise as consumers worked out how best to shop in the new formats. Customer learning was aided not only by the retailers but also a wider network including packaging manufacturers, brand marketers, and shop equipment suppliers who were also active in co-creating the supermarket. ${ }^{28}$ This is not to suggest, of course, that shoppers were always receptive to the exhortations of the 'supermarket industry'. Work in cultural studies reveals the potential for consumption to resist attempts to reorder the retail landscape. For de Certeau and his co-authors, in everyday practices, such as shopping and cooking, consumption reveals itself by its capacity to creatively use products imposed upon it 'by a mass distribution system that wants to conform the crowd to imposed models of consumption..., 29

Shopping is an activity that is contextualised within both normative societal and cultural discourses and personal narratives of life changes. ${ }^{30}$ At a general level, studies have illustrated the interdependence of retail innovation and shopping in the context of macro- 
socio-economic change. Sophie Bowlby, for example, illustrates the inter-relationship between spheres of work and home in women's lives by reference to changes in food retailing during the 1960s, with its growing emphasis on convenient shopping environments for the busy woman increasingly likely to be in paid employment outside of the home. ${ }^{31}$

Supermarket shopping typically represents a good example of a so-called 'ordinary consumption' practice, with its focus on the inconspicuous, conventional and routine. ${ }^{32}$ Experiences in the supermarket generally revolve around the comparatively mundane, less memorable tasks of shopping for basic goods. As Strasser observes, 'few seek their entertainment in the dinnertime run to the supermarket. ${ }^{33}$ However, this is not to suggest that supermarket shopping is always devoid of higher-level experiences and related emotions. ${ }^{34}$ These can be deciphered in historical studies of retailing and shopping. For example, Rachel Bowlby in her own discussion on responses to the arrival of the supermarket in Britain chronicles some of the positive reactions to early supermarkets such as the sense of novelty people experience in being able to serve themselves. She also reminds us that shoppers' first interactions could also be characterised by considerable difficulty, as shoppers had to adapt to, and felt manipulated by, alienated, trapped, and under surveillance in the new shopping environments. ${ }^{35}$ Similarly, Alexander et al. illustrate how the socially-embedded nature of female food shoppers' activities, tied to discourse on the identity of the post-war housewife, could influence their engagement with emerging retail formats and make food shopping a more intensely reflective activity than we might otherwise expect. ${ }^{36}$

Historical analyses of the role of brands and of merchandising are also informative in assessing the place of experiences and meanings in early supermarket shopping. In relation to 
brands, Davies and Elliott contend that they increasingly played a dual role in the post-war supermarket, as a means to assist in making choices between the increased numbers of goods, and as a mechanism for the construction of identity. ${ }^{37}$ In this process of identity construction, as elsewhere, consumers were beginning to play a more active role. ${ }^{38}$ Similarly, du Gay notes that contemporary trade sources pointed retailers toward the importance of the 'personalisation' of merchandising. ${ }^{39}$ The significance of these findings is illuminated by our discussion of co-creation for, as Agnew suggests, 'it is not the meanings that merchandisers give but the meanings that customers take that count. ${ }^{40}$ Developments in brand management and merchandising assisted shoppers' determination of the potential symbolic and functional value to be gained through shopping at the new supermarkets.

\section{THE DEVELOPMENT OF SUPERMARKET RETAILING: UNDERSTANDING THE SHOPPER'S PERSPECTIVE.}

The number of self-service stores in Britain grew from as few as 10 in 1947, to an estimated 500 or so by $1950 .{ }^{41}$ Later estimates suggested that there were as many as 6,300 self-service stores by 1960 , and more than 28,000 in operation by the end of that decade. ${ }^{42}$ An increasingly significant amount of self-service retailing was taking place in larger supermarket formats which began to appear in Britain during the 1950s, although attempts to differentiate between supermarkets proper and other large self-service formats proved challenging even for contemporary industry analysts. ${ }^{43,44}$ The best estimates, however, reported that there were around 50 supermarkets in existence in 1950, swelling in number to 
572 by $1961 .{ }^{45}$ By 1969 there were an estimated 3400 supermarkets in Britain. ${ }^{46}$ These stores were typically smaller than their counterparts in North America. A minimum sales area of only 2000 sq. ft. was adopted as a benchmark in early attempts to define the format during the late 1950s, and it was suggested that in 1967 the typical supermarket in Britain was still only some 4000 sq. ft. in size. ${ }^{47}$ Nonetheless, Nielsen reported that self-service operations (both self-service stores and supermarkets) accounted for $15 \%$ of grocery turnover in 1959 , rising to as much as $64 \%$ only ten years later. ${ }^{48}$

The degree to which the success of the supermarket depended on altered inputs from shoppers is reflected in the concerted and prolonged efforts of goods manufacturers and retailers to understand shoppers' reactions to the changing service encounter. The housewife was the target of such enquiries. ${ }^{49}$ One of the earliest studies to directly garner the shopper's viewpoint on the self-service approach to retailing was the British Market Research Bureau's (hereafter BMRB) 1950 Self-Service in Great Britain. This report reflected '[t]he extent to which self-service will be taken up as a new method of retailing food depends ultimately on what the customers think of the system. If they do not take to it kindly, it will never become firmly established. ${ }^{50}$ A number of shopper surveys followed during the next two decades that, among other aspects of shopper attitudes and behaviours such as frequency and timing of shopping trips, distances travelled to shops, and loyalty to particular retailers, gave detailed attention to reporting their reactions to the increasingly rapid pace of change to self-service approaches and particularly to the new supermarket format. ${ }^{51}$ The intention was to provide a detailed picture of the likes and dislikes of shoppers 'as seen through her own eyes and with her own comments on it. ${ }^{52}$ 
The concern reflected in these surveys was, increasingly, not whether self-service and the supermarket would become firmly established, but whether supermarkets were meeting the real needs of shoppers. Even BMRB's occasionally cautionary analysis in 1950 acknowledged that 'the ground has been prepared for the spreading of self-service in this country. ${ }^{53}$ In the series of studies that followed, attention increasingly turned to the potential of the supermarket format to extend its influence. Arguing that it was insufficient to say that supermarkets are ‘doing well’, J. Walter Thompson’s (hereafter JWT) 1963 publication Shopping in Suburbia, commissioned by the retailers Premier Supermarkets and W. H. Smith, turned its attention to a series of issues that potentially jeopardised customer loyalty, seeking answers to questions such as the reasons some customers failed to do a one-stop shop at the supermarket and, more particularly, why shoppers were seemingly unconvinced about prepackaged perishable foods. The subtitle to JWT's follow up study, The Changing Face of Supermarket Shopping, asked the question: “Are supermarkets making the progress they expected in gaining the affection of the housewife?' It concluded that their record of growth was impressive, but that one might still question whether they represented the 'housewife's choice. ${ }^{54}$ For JWT, supermarket firms were not yet offering sufficiently differentiated images to allow customers either to develop firm loyalty or indeed 'to indulge a taste for variety. ${ }^{, 55}$ Six years on from this, the International Publishing Company's report Shopping in the Seventies would declare that 'the age of universal supermarket shopping has arrived.' Its authors considered that any future growth had to come from 'winning further custom from existing shoppers rather than attracting new customers. ${ }^{56}$

Contemporary studies of consumer reactions to the supermarket thus reveal a shift in concern from anxiety about shoppers' responses to the self-service approach, to concerns with how to build and deepen customer loyalty to particular supermarket retailers. What remained 
constant was the extent to which understanding the reactions of the consumer were of central importance. Such understanding would help modify some of the assumptions about the consumer made by retailers during the innovation process. ${ }^{57}$

\section{METHOD: ORAL HISTORIES AND THE VALUE OF THE RETROSPECTIVE}

\section{APPROACH}

Forefronting the role of consumers in innovation requires methodological approaches that enable us to reconstruct not only how consumers perceived innovations, but also how they engaged with them, and, more broadly, an appreciation of the social context in which they were situated and which, therefore, informed their participation in the process.

Structured survey questionnaires and semi-structured interviewing have longstanding acceptance as methods for researching consumer behaviour, including in relation to shopping. ${ }^{58}$ The wider project from which this paper is drawn makes use of both shopper's biographical questionnaires and oral history interviews in a retrospective approach which asked interviewees and respondents to reflect on their attitudes and behaviours toward selfservice and supermarket retailing and shopping between 1945 and $1975 .{ }^{59}$ In this study we concentrate our analysis on the oral history data, which provides particularly rich material for revealing the complexities of the co-creation process. ${ }^{60}$ 
One hundred and twenty-two people who remembered shopping between 1945 and 1975 were interviewed; twenty-six of these were men and ninety-six were women between the ages of fifty-three and ninety-three. Interviewees were contacted on the basis of information they were invited to provide on the survey questionnaire and they were selected predominantly in five geographical regions, the South East of England, London, and the South West, North West and West Midlands of England, although their shopping experiences were more geographically diverse. This design reflects one of the wider project objectives; to uncover any differences resulting from regional variations in the timing and extent of supermarket development. Interviews were conducted according to a semi-structured interview schema, with interviewees being asked about their shopping behaviour throughout the period covered by the study. While our retrospective approach was in part dictated by the post-war timing of supermarket innovation in Britain, it also offered the benefit of facilitating reflections on the evolution of shoppers' relationships to supermarkets over a three- or fourdecade perspective. Interviewees could identify changes in their behaviour and attitudes to supermarkets throughout their lives - how they learnt new approaches to shopping, how the changing circumstances of their lives affected their use of supermarkets, or how supermarkets themselves changed over time.

Our approach to the oral history data analysis comprises of two related strands. In the first strand we undertook a content analysis of the data concerned with shoppers' recollections and reflections of their very first experience of supermarket shopping. We began by developing a list of twenty-one codes to represent the themes associated with shopping in early supermarkets. This was based upon those identified in JWT's Shopping in Suburbia. The codes incorporate several factors that relate explicitly to the issues of co-creation including 'helping yourself', 'interacting with shop staff' 'other shoppers/crowded', 'fun and 
excitement' and 'friendliness' as well as others in which the co-creative role of the consumer is perhaps less self-evident. In addition, we added the code 'having to learn new ways of shopping/adapt' given its potential significance to co-creation, particularly in relation to the development of shopper know-how and competences. As is consistent with the content analysis method, the twenty-two codes were defined in precise terms to ensure they could be universally understood and that any researcher using the code book could readily identify which code applied to a particular piece of text.

In most of our interviews, interviewees were asked to discuss their first recollections of supermarket shopping. These were typically responses to the open-ended question, 'Tell me about your first experience of a supermarket.' Our intention was to leave the question sufficiently open to encourage interviewees to describe their experience in terms, and with emphases, which made most sense to themselves. Having collected these recollections, we subjected the interview material to content analysis to ascertain the relative significance of issues relating to co-creation that were highlighted by shoppers in the service interaction. Content analysis enables researchers to interrogate a text systematically to determine the respective relevance of key ideas or themes and has been a recognised method in consumer research since Harold Kassarjian's 1977 article in the Journal of Consumer Research. ${ }^{61}$

Of the interviews undertaken for the project, a total of sixty-eight have to date been verbatim transcribed and then coded using the qualitative analysis package, NVivo 7. Interview material discussing shoppers' first experiences of supermarket shopping constituted 23,175 words in forty-nine interviews. Of these, forty-six were suitable for content analysis on the theme of first experience of a British supermarket. This 'first experience' material was then 
subjected to a coding process on the basis of our twenty-two codes. Our coding focused on whether or not a particular theme appeared in the interview text at any point, not the frequency of such mentions. For example, if feelings of excitement or enjoyment associated with shopping were mentioned by the same interviewee several times, it was simply recorded once as having been mentioned. ${ }^{62}$

The content analysis of interviewee responses to the open-ended question on their first experience of supermarkets constituted one strand of the oral history analysis. The second involved an initial reading and subsequent NVivo 7 -assisted analysis of material from semistructured interview questions which situated shopping within interviewees' lives over a longer period. This enabled the wider relevance of the co-creation theme to be identified. Interviewee reflections on their first experience of supermarket shopping constitute memory events that occurred over a relatively short time frame and which were, by definition, novel. By contrast, our other questions asked interviewees to discuss their routine shopping habits, and reveal periods of both continuity and change over a three-decade period.

Semi-structured oral history interviewing is characterised by the interaction between the interviewee and interviewer, and the emphasis on situating of recollections of individuals within the narrative context of their lives. ${ }^{63}$ This allows interviewees considerable latitude in their responses and enables them to confirm or reject perspectives offered on events by the interviewer. Interviewees also have scope to introduce new issues, perspectives, and emphases which are most relevant to them. We found that interviewees could readily identify how changes in their work and family lives affected their shopping behaviour throughout the decades, as they intuitively wove life experiences into their narratives of food shopping. The 
extent to which oral testimonies situate experiences within the life histories of individuals has been one of the significant advantages for us in the method we adopted.

\section{THE SHOPPER'S PERSPECTIVE ON CO-CREATION}

Our content analysis of interviewees' first encounter with supermarket shopping clearly illustrates the significance of the co-creation process among our interviewees. Among the most remarked upon themes was that of 'helping yourself', which incorporates discussion of both the altered patterns of work in shopping and the shoppers' role in generating value from the retailers' offer. As we expected, the need to learn new ways of shopping and to adapt was also comparatively frequently remarked upon; it was mentioned more frequently than the availability of new products. Ten of our forty-six interviewees mentioned interactions with staff, highlighting the relevance of altered shopper-staff interactions to the supermarket service encounter. Whilst partly expected given our focus here on shoppers' first encounters with supermarket retailing, the comparatively large number of references to excitement and fun reveals the significance of novelty of experience and the resulting emotions in the switch to the supermarket environment. This focus on first encounters might also provide some explanation for shoppers' reflections of the supermarket environment as being 'friendly' and the absence of any mentions of it leading to feelings of anonymity. As observed below, our analysis of the broader discussions of the nature of supermarket shopping, which embrace a longer-term reflection of shoppers' engagement with the format, provides a sometimes 
differing picture with regard to the issue of anonymity. A similar observation is made in relation to shoppers' examinations of the quality of the goods for sale.

\section{[Insert Figure 1 here]}

\section{Co-production: the shopper at work}

Only a minority of our interviewees commented explicitly on the notion of supermarket shopping as being more physically laborious, that is to say as requiring an alteration in the distribution of physical work between the shopper and retailer. Those who did connected this with a perceived lack or decline in service on the part of the retailer, as illustrated by the following comment from one of our participants: "You did get people moaning, 'I asked that assistant where the porridge was and do you think she'd move her body from that counter, no she did not, I had to go and look for it myself'.",64

Some reflected directly upon the division of labour within the new retail environment of the supermarket. When asked by the interviewer whether she felt she was doing the work of the shopkeeper in the early supermarkets, Helen replied:

'No, no, never. No because they had checkout girls didn't he? And you didn't fill the shelves you [were] just went 'round and helped yourself ...I think it might have been different if you'd just had a basket and you'd had to carry the bloomin' stuff 'round in a basket but you didn't; you had a trolley to pull. ${ }^{65}$ 
Shoppers' mixed reactions to being required to handle and transport their goods are frequently commented upon in historical accounts of the rise of the supermarket. ${ }^{66}$ It was also mentioned on many occasions by our participants, and often closely associated with a liking of being able to select goods for oneself. As such this may be viewed as a dynamic which gave precedence to the shoppers' knowledge and preferences.

As one respondent told us on shopping for greengrocery:

'I can remember going in there and ladies saying "I don't want to pick potatoes up" and I used to think well I bloody do because you can see what you're getting...,67

The need to adapt and learn in the new retail environment came across clearly in our interviews. Despite the comparatively small size of the early supermarkets our respondents frequently reflected upon the new shopper-skills, or know-how, they needed to develop as they began to use them. One early supermarket shopper reflected:

'And they [United Dairies] were the first ones to actually turn over and I think it must have been very early 60's. Late '50s, early 60's and they were the first ones that turned over and oh my goodness, you'd go in there and everything's out on the shelves and oh yeah this is different and, and that was about the first experience. In those shops and then the Co-op there was a Co-op in Replingham Road and then they did it and you sort of walked round and got your own things. "Oh this is incredible."

[interviewer]... did it seem obvious to you to know how to shop in this self-service store? 
No, really, no no you had to sort of learn all over again. I mean you'd walk 'round and, and find where things were and of course then when the, when the um supermarket, self-service type of shops came in you had things like the sugar bagged and the sweets in um, biscuits in packets. ${ }^{, 68}$

As retailers developed new, larger supermarket formats so the shopper had to familiarise herself with the new store environment offering a wider range of products and services, many new and often displayed and packaged in unfamiliar ways:

'. Tesco opened - the big Tesco -they took over the cinema, there was a cinema there, and er they made that into that vast - that was the biggest one you know we knew. That was the first time that we knew there were supermarkets that size. And you felt lost in there - there was- I mean you know you had so many aisles and so many columns and things and it, it confused us. We hadn't been used to seeing those sort of things. You imagine, you think of a cinema. Er, you know, emptied of all the seats un it was vast, it really was I mean you went in main door and then you got the aisles in front of you...[but] you had ohh going far back you know and everything you could imagine. ${ }^{69}$

Some interviewees reflected on the learning strategies involved. Margaret told us:

'So what I used to do was make my list from a map of the shop in my head [ ] I used to have a map of the shop in my head. So the first time I went in I didn't go in to do 
the shopping, I went and bought something but had a jolly good look around and found out how it all worked..., ${ }^{70}$

Alongside understanding how the mechanics of the supermarket environment worked was the need to be appreciative of the possible dangers of the new way of shopping. The physical separation of aisle (choosing) and checkout (purchasing) needed careful negotiation. ${ }^{71}$ Margaret continued:

'...The other thing was not to overspend, you know not to go picking things up that you couldn't afford which was a great temptation to people I think and people did get in a mess with it or go picking up silly things that were not essentials. ${ }^{, 72}$

\section{Value creation: experiences in the aisles}

As we have discussed, food shopping typically represents a good example of a so-called 'ordinary consumption' practice. Nonetheless, the initial switch to supermarket shopping could generate a variety of emotions. For some the earliest experiences offered novelty and a sense of fun. One interviewee recalled

'I can remember going into one of the Victor Value with my, with one of my auntie..., and we were just shrieking with laughter because it seemed so, oh, oh, we're taking things off the shelves ourselves, you know um mind you the man was watching us like a hawk um so that was, that was just a lark...,73 
Whilst certainly not universal, new supermarket openings could also generate excitement for shoppers and were sometimes viewed as a representation of wider meanings. In this context fewer of our interviewees mentioned the notion of the 'Americanisation' of shopping on their own volition than we had expected given the predominance of debates on the influence of American retailing methods in the contemporary trade press and given its place in narratives of the history of retail change post-war. ${ }^{74}$ However, those that did equate the supermarket with 'American' culture could present evocative recollections of the 'otherness' of the supermarket. Jeanette told us:

'Safeway opened at the other end of the High Street ...Um, so I was interested in Safeway, 'cos I read that Safeway was American, American owned and would be run on American lines which I found riveting 'cos people of my age, nearer, were really into films and things American were thrilling.[Yes]... Um, I couldn't wait to see it. ${ }^{, 75}$

This specific use of Safeway as an example is perhaps unsurprising given the firms novel use of 'American' concepts such as the in store snack bar and pram park. ${ }^{76}$ Indeed in completing our biographical questionnaire in advance of being interviewed Jeanette wrote that Safeway "was "Americanised" in the nicest way and it was a revelation - bright, clean, huge choice, innovative - and with even a cafeteria counter to get coffee etc! I thought I was in heaven. ${ }^{, 7}$

Many interviewees spoke to us of the other positive experiences that the supermarket could provide, some finding it liberating to pick up and handle goods and being able to input more directly into the selection process, others welcoming what they perceived as being the lesscontrolled environment of the supermarket, being able to browse without purchasing. However, as we expected, experiences were not always positive. Yet others spoke of new pressures and anxieties that the supermarket shopper felt as a result of the altered ways in 
which they were put to work in the service encounter. Included among these were concerns over what were considered the invasive customer surveillance techniques employed by some supermarket retailers and fears over possible wrongful allegations of shoplifting. ${ }^{78}$ Fairly typical of the type is the following reflection from Elaine:

'I mean there were, on TV there were reports of some famous people who' $\mathrm{d}$ been taken to court and really embarrassed and so on because they'd left something in the trolley and wheeled it through, yes I was quite conscious of how easily you could do that. Yes it's quite frightening really! Or simply just by being absent-minded, you know, and slipping something, instead of putting it into the trolley, putting into your bag or whatever. ${ }^{79}$

Cognisant that the development of the supermarket could lead to an alteration in the social contact involved in shopping, commercial and academic researchers alike quickly turned their attention to the new type of service encounters that could result. ${ }^{80}$ The removal of counterservice did not of course entail the removal of all vestiges of shopper-staff interaction prior to the checkout. Staff members were still present on the shop floor in various capacities, as shelf fillers, greeters and managers. Some retailers maintained specialised staff- service in some food sections, particularly butchery, and others purposely trialled customer advisers, employed to provide shoppers with information on recipes and answer questions on methods of preparation, in an effort to breakdown the perceived isolation of the shopping environment. $^{81}$

Like their customers, supermarket employees were also developing new roles and know-how. In early experimentations this could apparently affect the atmosphere in store. This provides 
an alternative perspective to contemporary reports that shoppers perceived the supermarket environment as one that lacked friendliness. ${ }^{82}$ One interviewee recollected:

'...I think in the early days they were trying to find their feet and the customers were trying to find their feet so therefore there was um, um not a lot of banter or rapport because they were trying so hard to have it clean and packed and the shelves packed... and you were sort of looking 'round wondering where it is and what is was and .. I think it is only usage has made us accept and familiarise ourselves with it..., ${ }^{83}$

Industry observers commented on the changing nature of the relationship between shop staff and shopper. ${ }^{84}$ Small supermarkets, particularly those with smaller rural catchments, could retain much of their previous character despite the removal of counters. As Janet reflected of her early supermarket shopping experiences:

'where it's only a small community, you still know the people so there's still a bit of chatter sort of thing because you know them, the same as you did in the counterservice ones. ${ }^{, 85}$

Nonetheless, in larger supermarkets many of the hitherto usual opportunities for interaction between customers and staff, and between one customer and another could be either altered or lost. McClelland explained this in relation to numerous factors including the greater through flow of customers, themselves probably drawn from a wider catchment, shift and part-time working practices, job specialisation, the increased role of advertising and branding and the removal of many preparatory tasks from the sales floor. ${ }^{86}$ Interestingly, anonymity and isolation were not emphasised as characteristics of the supermarket by any of our interviewees when they were asked to reflect on their first experience of supermarket 
shopping. However, several pointed to these factors as part of their reflections of shopping at the supermarket over the longer-term. One interviewee expressed very negative feelings in this regard, considering the new supermarket environment to be more like a factory than the counter-service retail environments she was used to. ${ }^{87}$ Yet, for some others the anonymity possible in the supermarket was far from being a negative characteristic. As Pierre Mayol has observed, the social relationships, hierarchies and roles of the neighbourhood are carried into, and 'polished up', in the shop. ${ }^{88}$ Counter-service food shops could become the place for unwelcome scrutiny, especially for people who felt in some way marginalised, for example they were younger than other shoppers, or new to the area, or less well-off than their neighbours. Margaret remembered:

'The other thing is listen to all your business!...into everybody else's business and by the time you went home, you knew everybody else's business apart from you own because everybody else knew it didn't they? And it was just- that's what I didn't like about the small shops...,89

Similarly, the altered interaction with sales staff in the supermarket was reported as a welcomed feature by a number of our interviewees who stressed what they perceived to be the more equitable nature of shopping with goods openly on display for all to see, not hidden away for distribution to favoured customers. Other respondents told us of their dislike of what they considered to be the constant interruption and badgering of counter-service sales staff, the feeling of being compelled to buy something rather than to browse and the embarrassment that could be suffered in buying small quantities or cheaper variants of products. Sociological analyses of the period may have concluded that housewives were realistic about the motivations and commercial character of the shopkeeper's task, but counter-service contained its own particular frustrations. ${ }^{90}$ 
It was particularly the customer-cashier interaction that came to typify the human aspect of the altered service encounter in the supermarket and the checkout cashier quickly became the subject of attention of retailers and researchers alike. As their experience of supermarket retailing increased, the personnel departments of firms like the London Co-operative Society became increasingly focussed on the need to find suitable employees for this semi-skilled role. ${ }^{91}$ Management theorists concerned with service quality have pointed toward the centrality of the cashier's role and highlighted the tension between customer and cashier as each sought to wrest control of the service encounter. ${ }^{92}$

Shopper-checkout cashier interaction was also widely remarked upon in our oral histories. The checkout was frequently pointed to as one of the few places for social exchange, but for some of our respondents this appeared not to extend to discussion with other shoppers. As Elaine explained:

'I can't remember ever really having a conversation with anybody in the queue and that was a difference because as I say, at the corner shop, while you were waiting, you would always engage in conversation... rarely did you engage in a real conversation with anyone. So you would just wait there and sort of, daydream or your eyes would be going around the shop or whatever. Occasionally I would exchange a few words with the girl on the till but very rarely with anybody in the queue. ${ }^{93}$

Supermarket retailers were understandably concerned about shoppers coming to view the supermarket as being 'soulless'. McClelland pointed to the pressures upon the cashiers that could inhibit their interaction with the customer; ensuring the basket is properly positioned, the need to concentrate on the practice (rhythm) of ringing up the goods to be purchased and 
the awareness of a queue at their station. ${ }^{94}$ Some of our respondents also sought to remind us that the interaction with checkout staff possible in today's supermarket was reduced in the early stores as a result of cashiers working with manual tills:

'...they didn't scan it then it was - it had to be tapped in didn't it, the price of everything so they were concentrating on what they were doing really, looking at the price and tapping it in because it wasn't scanned then, you know ... Not personal at all really was it? No they had to concentrate on what they were doing so there wasn't much ban[ter]- there's a little bit more banter now because it scanned so they do have time to smile at you..., 95

Finally, and as we have noted above, decisions over food shopping at the supermarket could be influenced by wider social and cultural discourses as they were by personal narratives of life changes. We turn to this briefly now by way of concluding this section. We do so mindful of its significance in illustrating the possible constraints placed upon the women food shopper despite the seemingly unbounded choices of the supermarket aisles and because of its relevance to consumers' determination of the supermarket retailers' value proposition. Unsurprisingly, some of our interviewees reflected on the wide variety of goods in the supermarket and most did so in relation to their dominant role as provider of food for the family. The emphasis was perhaps strongest among women who were in employment outside of the home, reflecting aforementioned links between the supermarket innovation and macroshifts in the organisation of society. We illustrate this with one of a number of similar quotes from our interviewees: 
'But when I did go back to work, that was when the supermarket was really handy. 'cos I just didn't have time to do the cooking, because before everything had to be made ..., everything had to be done from scratch. And you accepted it; that was what homemaking was about. But when you were at work you thought 'Can I have something quick?' So suddenly there were tins with pies already done in them... and all sorts of convenience food. So you, you know, could certainly, you could certainly manage things a lot quicker once the supermarkets and self-services came into being. 96

However, as JWT had suggested, it was unclear if the supermarket really represented the 'housewife's choice'. ${ }^{97}$ The risk of the supermarket to the housewife came not only in selecting too many goods for her available budget, but also in selecting 'inappropriate' goods, the perceived lack of quality of which could detract from her performance in her role as household food provisioner. These concerns were expressed most frequently in relation to the purchase of fresh goods such as meat and fruit and vegetables. ${ }^{98}$ The extent of the problem was such that the difficulty of selling perishable goods in supermarkets was given particular attention in the research underpinning JWT's Shopping in Suburbia. It quoted MassObservation research for the Economist Intelligence Unit that showed tinned goods, soap and detergent, butter and cheese, as the preferred goods to buy in a self-service store or supermarket. Bread and pastries, fruit and vegetables were among the least popular, and fresh meat was the least so. ${ }^{99}$ Here we see the intersection of the vociferous discourse surrounding the role of the post-war housewife and retail innovation, represented through the consumption choices made by the women food shopper; whether to shop at the new supermarkets and, if so, for what goods. ${ }^{100}$ It was also a point reflected upon by some of our respondents: 
'...you didn't want to buy your meat there or anything because it was pre-packed or pre-wrapped and it wasn't as good quality as you would have in the butcher's...so you would only buy basic cleaning goods and things. You wouldn't really want to although some people did use it presumably. But they were considered to be not proper housewives, really. And they weren't doing good housekeeping if they went to the supermarket. ${ }^{101}$

\section{CONCLUSION}

In this paper we have developed the notion of the co-creation of innovation as a framework for the analysis of the changing service encounter characteristic of the early supermarket in Britain. In doing so we extended upon an increasing acknowledgement within the literatures of business history, marketing, and the social sciences more generally of the central role of the consumer to the innovation process. Through our analysis of the ways in which consumers use and contribute to innovations in their everyday lives we contribute to an issue widely acknowledged of being in need of more study. ${ }^{102}$

We were particularly keen to analyse the multi-faceted nature of the shoppers' contribution to the supermarket innovation in order to extend discussion beyond the oft-mentioned redistribution of the physical labour of shopping from retailer to shopper. Our wider evaluation of the shoppers' contribution incorporated the need for renewed learning and competence development among shoppers as a result of the altered retail environment. Through this it extended to a consideration of the shopper's wider role in value creation as 
part of the co-creation process. With regard to the latter we have examined some of the ways in which both the shopper's individual circumstances, and the wider social-cultural contexts that underpinned shopping could influence their evaluation of, and propensity to unlock the potential value in the supermarket retailers' proposition.

The paper considered existing conceptual arguments in the light of a new collection of oral history data specifically gathered to enable analysis of consumers' reaction to the development of the supermarket. This new data source is a significant in moving us beyond an otherwise general reliance of the findings of a small number of contemporaneous market research reports of the topic. Analysis of this oral history data confirmed the significant role of early supermarket shoppers in both co-production and value creation. Our interviewees gave less emphasis to co-production in terms of doing the physical work of shopping in the supermarket than one might expect given the existing literature. They more frequently drew our attention to their enhanced role in undertaking the mental work of shopping, particularly referring to the need for new shopper competences and learning surrounding the practise of choosing goods for oneself; acts which privilege the customer's knowledge and preferences. Our interviewees also revealed the place of experiences to their involvement in the cocreation process and the emotions these engendered. The experiences referred to were often the rather mundane and habitual ones that have been widely connected with food shopping. ${ }^{103}$ However, our interviewees occasionally extended the discussion beyond this to include less routine experiences and explained the role of supermarket shopping in generating varied emotions such as excitement and (un)happiness. 
Our oral histories also point toward the sometimes constrained nature of shopper's interaction with the supermarket offer. This constraint came in part as a result of particular individual and familial contexts in which food shopping was conducted and such contexts were frequently referred to in the shopper histories we collected. More generally it came through the social-cultural contexts of shopping, that is to say through the intersection of supermarket shopping with the multiple discourses which permeated the lives of our shoppers. We limited ourselves to one illustration of such an intersection, in relation to post-war discourse on the 'good housewife', but its wider significance should be clear.

Shoppers' discussions of their co-creative roles were frequently structured around four aspects of alteration in the service encounter; shoppers' interaction with the changed physical environment of the store, with the goods for sale, with other shoppers, and with shop staff. The wider range of goods for sale in the new supermarkets, and the role that the branding of these goods played was the subject of attention of contemporary market research reports as it has been in subsequent historical analyses. ${ }^{104}$ In this article we have also illustrated the importance of the other three aspects which structured our interviewees' discussions.

Reorienting analyses of retail innovations, including the early supermarket, to consider the input of the shopper offers a number of opportunities for further study. For example, the supermarket has been shown to have developed through a stage-like development pattern, with more advanced formats emerging from prototypical examples. ${ }^{105}$ What is less clear at present is the extent to which the shopper's contribution to the recursive nature of supermarket innovation is constant over both time and space or reveals distinct periodicities and geographies. ${ }^{106}$ Similarly, our focus in this paper has been on evaluating the shoppers' 
role in co-creation, rather than the retailers' or that of other network members. Our reading would suggest that early supermarket retailers were only in the initial stages of acknowledging and seeking to better manage the capacity of shoppers to contribute to the value creation activity, being still more inclined to order and classify their target market through market research than engage in meaningful dialogue with shoppers to enable learning together. ${ }^{107}$ However, this is a topic that demands further research before we can draw a definitive conclusion. 


\section{BIBLIOGRAPHY}

\section{Books}

Roger R. Betancourt, The Economics of Retailing and Distribution, Cheltenham: Edward Elgar, 2004

Wiebe E. Bijker, Thomas P. Hughes and Trevor Pinch eds., The Social Construction of Technological Systems. New Directions in the Sociology and History of Technology, London: MIT Press, 1987

Wiebe E. Bijker, Of Bicycles, Bakelites, and Bulbs: Toward a Theory of Sociotechnical Change, London: MIT Press, 1992

Johnston Birchall, Co-op: The People's Business, Manchester: Manchester University Press, 1994

Alfred Bird and Sons Ltd., (first edition) Mrs Housewife and Her Grocer, London: Alfred Bird and Sons, 1958

Alfred Bird and Sons Ltd., (second edition) Mrs Housewife and Her Grocer, London: Alfred Bird and Sons, 1961

British Market Research Bureau Ltd., Self-Service in Great Britain: A Study of the Latest Method of Grocery Retailing, London: British Market Research Bureau Ltd, 1950

Rachel Bowlby, Carried Away: The Invention of Modern Shopping, London: Faber and Faber, 2000

Michel de Certeau, The Practice of Everyday Life, London: University of California Press Ltd., 1984 
Victoria de Grazia, Irresistible Empire: America's Advance Through 20th-century Europe, Cambridge MA: The Belknap Press of Harvard University Press, 2005

Christina Fulop, Competition for Consumers: A Study of the Changing Channels of Distribution, London: André Deutsch, 1964

Jukka Gronow and Alan Warde eds., Ordinary Consumption, London: Routledge, 2001

Kim Humphery, Shelf Life. Supermarkets and the Changing Cultures of Consumption, Cambridge: Cambridge University Press, 1998

Timothy Joyce, The New Housewife, London: British Market Research Bureau Ltd, 1967

IPC, Shopping in the Seventies: Highlights of a Survey of Housewives, London: Women's Weekly Group, International Publishing Company, 1970

JWT, Shopping in Suburbia: A Report on Housewives' Reactions to Supermarket Shopping, London: J Walter Thompson Co. Ltd, 1963

JWT, The Changing Face of Supermarket Shopping: Are Supermarkets Making the Progress They Expected in Gaining the Affection of the Housewife? London: J Walter Thompson Co. Ltd, 1964

Ronald R. Kline, Consumers in the Country: Technology and Social Change in Rural America, Baltimore MD: John Hopkins University Press, 2000

James M. Mayo, The American Grocery Store: The Business Evolution of an Architectural Space, Westport: Greenwood Press, 1993

Daniel Miller, A Theory of Shopping, Cambridge: Polity Press, 1998 
Daniel Miller, Peter Jackson, Nigel Thrift, Beverley Holbrook, Michael Rowlands, Shopping, Place and Identity, London: Routledge, 1998

David E. Nye, Electrifying America. Social Meanings of a New Technology, 1880-1940, Cambridge Mass.: MIT Press, 1990

Organisation for European Economic Co-operation (OEEC), The Economic Performance of Self-Service in Europe, Paris: OEEC, 1960

Nelly Oudshoorn and Trevor J. Pinch eds., How Users Matter: the Co-Construction of Users and Technology, London: MIT Press, 2003

B. Joseph Pine II and James H Gilmour, The Experience Economy. Work is Theatre and Every Business a Stage, Boston Mass.: Harvard Business School Press, 1999

Alessandro Portelli, The Death of Luigi Trastulli and Other Stories: Form and Meaning in Oral History, New York: SUNY Press, 1991

Dominic Sandbrook, Never Had it so Good. A History of Britain from Suez to the Beatles, London: Abacus, 2006

Elizabeth Tonkin, Narrating Our Pasts: The Social Construction of Oral History, Cambridge: Cambridge University Press, 1992 Jan Vansina, Oral Tradition as History, Nairobi: James Currey, 1985 Bridget Williams, The Best Butter in the World. A History of Sainsbury's, London: Ebury Press, 1994

Max Mandell Zimmerman, The Supermarket: A Revolution in Distribution, New York: McGraw-Hill, 1955 


\section{Articles}

Andrew Alexander, Gareth Shaw and Louise Curth, "Promoting Retail Innovation:

Knowledge Flows During the Emergence of Self-Service and Supermarket Retailing in

Britain", Environment and Planning A 37 (5) (2005): 805-21

Andrew Alexander, Simon Phillips and Gareth Shaw, "Retail Innovation and Shopping

Practices: Consumers' Reactions to Self-Service Retailing”, Environment and Planning A 40

(9) (2008): 2204-21

Andrew Alexander, "Format Development and Retail Change: Supermarket Retailing and the London Co-operative Society”, Business History 50 (4) (2008): 489-508

Eric J. Arnould, "Service- Dominant Logic and Consumer Culture Theory: Natural Allies in an Emerging Paradigm", Marketing Theory 6 (3) (2006): 293-7

Neeli Bendapudi and Robert P. Leone, "Psychological Implications of Customer Participation in Co-Production", Journal of Marketing 67 (January) (2003): 14-28

S.R. Bowlby, "Planning for Women to Shop in Postwar Britain", Environment and Planning D: Society and Space 2 (2) (1984): 179-99

Ian Clarke, Alan Hallsworth, Peter Jackson, Ronan de Kervenoael, Rossana Perez del Aguila and Malcolm Kirkup, "Retail Restructuring and Consumer Choice 1. Long-Term Local Changes in Consumer Behaviour: Portsmouth, 1980-2002”, Environment and Planning A 38 (1) (2006): 25-46.

Andrea Davies and Richard Elliott, "The Evolution of the Empowered Consumer”, European Journal of Marketing 40 (9/10) (2006): 1106-21 
John Dawson, "Output Considerations in Retail Productivity", the International Review of Retail, Distribution and Consumer Research 15 (3) (2005): 337-49

Robyn Dowling, "Femininity, Place and Commodities: A Retail Case Study", Antipode 25 (1993): 295-319

Paul du Gay “Self-Service: Retail, Shopping and Personhood”, Consumption, Markets and Culture 7 (2) (2004): 149-63

Michael Etgar, “A Descriptive Model of the Consumer Co-Production Process", Journal of the Academy of Marketing Science 36 (1) (2008): 97-108

Faïz Gallouj and Olivier Weinstein, "Innovation in Services", Research Policy, 26 (1997): $537-56$

Arieh Goldman, "Stages in the Development of the Supermarket", Journal of Retailing, 51 (4) $(1975 / 6): 49-64$

Peter Jackson, Rossana Perez del Aguila, Ian Clarke, Alan Hallsworth, Ronan de Kervenoael and Malcolm Kirkup, "Retail Restructuring and Consumer Choice 2. Understanding Consumer Choice at the Household Level", Environment and Planning A 38 (1) (2006): 4767

Harold H. Kassarjian, "Content Analysis in Consumer Research", The Journal of Consumer Research 4 (1) (1977): 8-18

Richard H. Kolbe and Melissa S. Burnett, "Content-Analysis Research: An Examination of Applications with Directives for Improving Research Reliability and Objectivity", The Journal of Consumer Research, 18 (2) (1991): 243-50 
Robert F. Lusch, Stephen L. Vargo and Matthew O'Brien, “Competing Through Service: Insights from Service-Dominant Logic”, Journal of Retailing 83 (2) (2007): 5-18

W Grigor McClelland, “The Supermarket and Society”, Sociological Review 10 (2) (1962): $133-44$

W Grigor McCelland, "Economics of the Supermarket”, The Economic Journal 72 (285) (1962): 154-70

Andrew McMeekin and Dale Southerton, "Innovation and Final Consumption: Social Practices, Instituted Modes of Provision and Intermediation”, CRIC Discussion Paper 79, Manchester: Centre for Research on Innovation and Competition, University of Manchester, January 2001

Dawn Nell, Andrew Alexander, Adrian Bailey and Gareth Shaw, "Investigating Shopper Narratives of the Supermarket in Early Post-War England, 1945-75”, Oral History 37 (1) (Spring) (2009): 61-73

Simon Phillips, Andrew Alexander and Gareth Shaw, "Consumer Misbehavior: The Rise of Self-Service Grocery Retailing and Shoplifting in the United Kingdom c.1950-1970”, Journal of Macromarketing 25 (1) (2005): 66-75

Anat Rafaeli, "When Cashiers Meet Customers: An Analysis of the Role of Supermarket Cashiers", Academy of Management Journal 32 (2) (1989): 245-73

Philip Scranton "Book Reviews: How Users Matter: The Co-Construction of Users and Technology", Technology and Culture 46 (4) (2005): 818-20 
Gareth Shaw, Louise Curth and Andrew Alexander, "Selling Self Service and the

Supermarket: The Americanisation of Food Retailing in Britain", 1945-1960", Business History 46 (4) (2004): 568-82

Gareth Shaw and Andrew Alexander, "British Co-operative Societies as Retail Innovators: Interpreting the Early Stages of the Self Service Revolution”, Business History 50 (1) (2008): $62-78$

Cyril Sofer, "Buying and Selling: A Study in the Sociology of Distribution", Sociological Review 13 (2) (1965): 183-209

Susan Strasser, "Making Consumption Conspicuous. Transgressive Topics Go Mainstream", Technology and Culture 43 (4) (2002): 755-70

Frank Trentmann, "Beyond Consumerism: New Historical Perspectives on Consumption", Journal of Contemporary History 39 (3) (2004): 373-401

Stephen L. Vargo and Robert F. Lusch, "Evolving to a New Dominant Logic for Marketing", Journal of Marketing 68 (1) (2004): 1-17

Stephen L. Vargo and Robert F. Lusch, "Service-Dominant Logic: Continuing the Evolution", Journal of the Academy of Marketing Science 36 (1) (2008): 1-10

Alan Warde "Consumption and Theories of Practice", Journal of Consumer Culture 5 (2) (2005): 131-53

Chunyan Xie, Richard P. Baggozi and Sigurd V. Troye, "Trying to Prosume: Toward a Theory of Consumers as Co-Creators of Value", Journal of the Academy of Marketing Science 36 (1) (2008): 109-122 
Joanne Yates, "How Business Enterprises Use Technology: Extending the Demand-Side Turn”, Enterprise \& Society 7 (3) (2006): 422-55

\section{Chapters}

Jean-Christophe Agnew, "The Give-and-Take of Consumer Culture”, in Commodifying

Everything: Relationships of the Market, ed. Susan Strasser, London: Routledge, 2003, 11-39

Madeleine Akrich, "The De-scription of Technical Objects”, in Shaping Technology/Building

Society. Studies in Sociotechnical Change, eds. W Bijker, J Law, London: MIT Press, 1992, $205-24$

Eric J Arnould, Linda L Price and Avinashe Malshe, “Toward a Cultural Resource-Based Theory of the Customer", in The Service-Dominant Logic of Marketing. Dialog, Debates and Directions, eds. Robert L. Lusch and Stephen L. Vargo, London: M.E. Sharp, 2006, 91-104 Adam Arvidsson, "Brand Management and the Productivity of Consumption", in Consuming Cultures, Global Perspectives. Historical Trajectories, Transnational Exchanges, eds. John Brewer and Frank Trentmann, Oxford: Berg, 2006, 71-94

Rachel Bowlby, "Supermarket Futures", in The Shopping Experience, eds. Pasi Falk and Colin Campbell, London: Sage, 1997, 92-110

Ruth Schwartz Cowan, “The Consumption Junction: A Proposal for Research Strategies in the Sociology of Technology”, in The Social Construction of Technological Systems, eds. Wiebe E. Bijker, Thomas P. Hughes and Trevor Pinch, London: The MIT Press, 1987, 26180 
Ken Ducatel, "Information Technologies in Non-Knowledge Services: Innovations on the Margin?" in Innovation Systems in the Service Economy. Measurement and Case Study Analysis eds. J Stanley Metcalfe and Ian Miles, London: Kluwer Academic Publishers, 2000: $221-246$

Richard Elliott and Andrea Davies, "Using Oral History Methods in Consumer Research”, in Handbook of Qualitative Research Methods in Marketing, ed. Russell W. Belk, Cheltenham: Edward Elgar Publishing, 2006: 244-54

Pim den Hertog, "Co-Producers of Innovation: On the Role of Knowledge Intensive Business Services in Innovation", in Productivity Innovation and Knowledge in Services. New Economic \& Socio-Economic Approaches, eds. Jean Gadrey and Faïz Gallouj, Cheltenham: Edward Elgar, 2002: 223-55

Luce Giard, "Introduction to Volume 1: History of a Research Project", in The Practice of Everyday Life. Volume 2: Living and Cooking, eds. Michel de Certeau, Luce Giard and Pierre Mayol, London: University of Minnesota Press, 1998, xiii-xxxiii

Ronald Kline, "Resisting Consumer Technology in Rural America: The Telephone and Electrification", in How Users Matter. The Co-Construction of Users and Technologies, eds. Nelly Oudshoorn and Trevor Pinch, London: The MIT Press, 51-66

Pierre Mayol, "Propriety", in The Practice of Everyday Life. Volume 2: Living and Cooking, eds. Michel de Certeau, Luce Giard and Pierre Mayol London: University of Minnesota Press, 1998, pp 15-34, quotation at pp.20-21

Daniel Miller, "Consumption as the Vanguard of History", in Acknowledging Consumption: A Review of New Studies, ed. Daniel Miller, London: Routledge, 1995, 1-57 
Brigitte Preissl, "Service Innovation: What Makes it Different? Empirical Evidence from Germany" in Innovation Systems in the Service Economy. Measurement and Case Study Analysis, eds. J. Stanley Metcalfe and, Ian Miles, London: Kluwer Academic Publishers, $2000,125-48$

Barbara Usherwood, “"Mrs Housewife and her Grocer’ The Advent of Self-Service Food Shopping in Britain", in All the World and Her Husband, eds. Maggie R. Andrews and, Mary M. Talbot London: Cassell, London, 2000, 113-30

Terrence Witkowski and D.G. Brian Jones, "Qualitative Historical Research in Marketing”, in Handbook of Qualitative Research Methods in Marketing, ed. Russell W. Belk, Cheltenham: Edward Elgar Publishing, 2006, 70-82

Sally Wyatt, "Non Users Also Matter: The Construction of Users and Non-Users of the Internet", in How Users Matter. The Co-Construction of Users and Technologies, eds. Nelly Oudshoorn and Trevor Pinch, London: The MIT Press, 67-79

\section{Newspapers and Magazines}

Anon., “The Self Service of Sainsbury’s”, JS Journal (July, 1967): 11

The Nielsen Researcher, “Annual Review: The Changing Pattern of Grocery Trading”, (March/April, 1963)

The Nielsen Researcher, "Future Trends in Packaged Goods", (September/October, 1970)

\section{Archives}


London Co-operative Society (LCS), No 2 Subcommittee reports 3 Sept 1962- 20 Jan 1964,

LCS Archive, London: Bishopsgate Institute.

${ }^{1}$ Bowlby, "Supermarket Futures," in Shopping Experience, eds. Falk and Campbell; Bowlby, Carried Away; du Gay, "Self-Service”; Shaw et al, "Selling Self-Service"; Alexander et al, "Promoting Retail Innovation"

${ }^{2}$ Some consideration of the goods for sale in the supermarket and the use of branding is provided by Davies and Elliott, "The Evolution of the Empowered Consumer"

${ }^{3}$ Our consideration of innovation incorporates innovation based upon entry into new markets. For a wider discussion see Preissl "Service Innovation” in Innovation Systems ed., Metcalfe and Miles

${ }^{4}$ Lusch et al, "Competing Through Service”

${ }^{5}$ Strasser, "Making Consumption Conspicuous", 762; Agnew, "The Give-and-Take of Consumer Culture" in Commodifying Everything, ed. Strasser

${ }^{6}$ Kline, "Resisting Consumer Technology" in How Users Matter eds. Oudshoorn and Pinch; Wyatt, "Non-Users Also Matter" in How Users Matter eds. Oudshoorn and Pinch

${ }^{7}$ Alexander et al, "Promoting Retail Innovation"

${ }^{8}$ See also Davies and Elliott, 'The Evolution of the Empowered Consumer'

${ }^{9}$ Strasser, "Making consumption conspicuous", 769

${ }^{10}$ Gareth Shaw and Andrew Alexander "Reconstructing Consumer Landscapes: Shopper Reaction to the Supermarket in Early Post-War England.”

${ }^{11}$ This is reflected in the use of different terms for the input process, including collaboration, co-construction, prosumption, co-production and more recently co-creation, as the respective debates have developed. We favour the use of the term co-creation as discussed below.

${ }^{12}$ Betancourt, The Economics of Retailing; Dawson, "Output Considerations"

${ }^{13}$ McClelland, "Economics of the Supermarket"

${ }^{14}$ Agnew, "The Give-and-Take of Consumer Culture" in Commodifying Everything, ed. Strasser; Bijker et al, The Social Construction of Technological Systems; Bijker, Of Bicycles, Bakelites and Bulbs; Kline, Consumers in the Country; Oudshoorn and Pinch, How Users Matter; Yates, "How Business Enterprises Use Technology"; 
Nye, Electrifying America; Cowan, "The Consumption Junction" in The Social Construction eds. Bijker,

Hughes and Pinch

${ }^{15}$ Oudshoorn and Pinch, How Users Matter; Strasser, "Making Consumption Conspicuous"

${ }^{16}$ Oudshoorn and Pinch, How Users Matter, 1

${ }^{17}$ Scranton, "Book Reviews: How Users Matter", 818

${ }^{18}$ Gallouj and Weinstein, "Innovation in Services"; Preissl, "Service Innovation" in Innovation Systems eds.

Metclafe and Miles; den Hertog "Co-Producers of Innovation" in Productivity Innovation eds. Gadrey and

Gallouj; Ducatel "Information Technologies" in Innovation Systems ed., Metcalfe and Miles

${ }^{19}$ Gallouj and Weinstein, "Innovation in Services", 546

${ }^{20}$ Vargo and Lusch, "Evolving to a New Dominant Logic"; Lusch et al, "Competing Through Service"; Vargo and Lusch, "Service-Dominant"; see also Bendapudi and Leone, "Psychological Implications"; Xie et al,

"Trying to Prosume"

${ }^{21}$ Lusch et al, "Competing Through Service", 8

${ }^{22}$ Lusch et al, "Competing Through service", 8

${ }^{23}$ Lusch et al, "Competing Through Service"; Etgar, "A Descriptive Model”

${ }^{24}$ Vargo and Lusch, "Service-Dominant"

${ }^{25}$ Arnould, "Service-Dominant Logic" in The Service-Dominant Logic eds. Lusch and Vargo

${ }^{26}$ See for example the discussion in Bendapudi and Leone, "Psychological Implications"

${ }^{27}$ See Miller et al, Shopping, Place and Identity on the unreflective nature of much food shopping activity

${ }^{28}$ For a further discussion on customer learning and attempts to educate the shopper see Dowling, "Femininity,

Place and Commodities"; Usherwood, "Mrs Housewife" in All the World, eds. Andrews and Talbot; du Gay,

"Self-Service"; Alexander et al, "Promoting Retail Innovation"; Alexander et al, "Innovation and Shopping

Practices"

${ }^{29}$ de Certeau, The Practice of Everyday Life, 31; Giard, "Introduction to Volume 1" in The Practice of Everyday

Life, eds. de Certeau, Giard, Mayol, xxii

${ }^{30}$ See Trentmann, "Beyond Consumerism"; Miller et al, Shopping, Place and Identity; Nell et al, "Shopper

Narratives"

${ }^{31}$ Bowlby, "Planning for Women to Shop"; see also Usherwood, "Mrs Housewife" in All the World, eds.

Andrews and Talbot; McMeekin and Southerton "Innovation and final consumption" 
${ }^{32}$ Gronow and Warde, Ordinary Consumption

${ }^{33}$ Strasser, "Making Consumption Conspicuous", 768

${ }^{34}$ See Pine and Gilmour The Experience Economy for a more detailed discussion on the importance of experiences

${ }^{35}$ Bowlby, Carried Away

${ }^{36}$ Alexander et al, "Innovation and Shopping Practices"; Jackson et al, "Retail Restructuring"; Miller A Theory of Shopping

${ }^{37}$ Davies and Elliott, "The Evolution of the Empowered Consumer", 1117

${ }^{38}$ Arvidsson, "Brand Management", 81

${ }^{39}$ du Gay, "Self-Service"; see also Alexander et al, "Innovation and Shopping Practices", Usherwood, "Mrs Housewife" in All the World, eds. Andrews and Talbot

${ }^{40}$ Agnew, "The Give-and-Take of Consumer Culture” in Commodifying Everything, ed. Strasser, 16

${ }^{41}$ Fulop, Competition for Consumers

${ }^{42}$ The Nielsen Researcher, 1963; 1970

${ }^{43}$ For a discussion of this see Alexander, "Format Development". An increasingly adopted definition of the supermarket was reported by McClelland in 1962 (McClelland, "Economics of the Supermarket", 154.)

${ }^{44}$ For a discussion on the development of the supermarket in North America see, for example, Zimmerman, The Supermarket; Goldman "Stages in the Development of the Supermarket"; Mayo, The American Grocery Store. For discussion on other European countries see OEEC, The Economic Performance; de Grazia, Irresistible Empire. On Australia see Humphery, Shelf Life

${ }^{45}$ McClelland, "Economics of the Supermarket"; Birchall, Co-op

${ }^{46}$ The Nielsen Researcher, 1970

${ }^{47}$ Anon., "The Self-Service of Sainsbury's"

${ }^{48}$ The Nielsen Researcher, 1970

49 Joyce, The New Housewife; see also Miller, "Consumption as the Vanguard of History" in Acknowledging Consumption ed. Miller; De Grazia, Irresistible Empire

${ }^{50}$ BMRB, Self-Service in Great Britain, 46

${ }^{51}$ Bird, Mrs Housewife; Bird, Mrs Housewife (second edition); JWT, Shopping in Suburbia; IPC, Shopping in the Seventies 
${ }^{52}$ Bird, Mrs Housewife, 5

${ }^{53}$ BMRB, Self-Service in Great Britain, 12

${ }^{54}$ JWT, The Changing Face of Supermarket Shopping, 3

${ }^{55}$ JWT, The Changing Face of Supermarket Shopping, 11

${ }^{56}$ IPC, Shopping in the Seventies, 4-5

${ }^{57}$ See Akrich "De-Scription” in Shaping Technology/Building Society, eds. Bijker and Law

${ }^{58}$ For a recent example of outputs from a project combining these two methods see Clarke et al, "Retail Restructuring"; Jackson et al, "Retail Restructuring"

${ }^{59}$ For a detailed discussion of the project methodology see Nell et al, "Investigating Shopper Narratives"

${ }^{60}$ See also the discussions in Xie et al, "Trying to Prosume"; Elliott and Davies "Using Oral History" in Handbook of Qualitative Research ed. Belk; Witkowski and Jones "Qualitative Historical Research" in Handbook of Qualitative Research ed. Belk; Humphery, Shelf Life

${ }^{61}$ Kolbe and Burnett, “Content-Analysis Research"

${ }^{62}$ One of the defining criteria for content analysis is that the process of coding should be replicable, principally that the codes are defined in such a way that different researchers could agree on whether a section of text belonged in a category or not (see Kassarjian, "Content Analysis", 9). It is common practise, therefore, for parallel coding to be undertaken to measure the degree of consistency between coders in applying the same set of codes to the same content. Our own small-scale exercise in parallel coding confirmed a high degree of consistency suggesting that the parameters for each code were sufficiently unambiguous.

${ }^{63}$ Vansina, Oral Tradition as History; Portelli, The Death of Luigi Trastulli; Tonkin, Narrating our Pasts

${ }^{64}$ Gill, OH/GC/F/--

${ }^{65}$ Helen, OH/491/F/1940

${ }^{66}$ See for example Williams, The Best Butter; du Gay, "Self-Service"

${ }^{67}$ Margaret OH/104/F/1932

${ }^{68}$ Joan, OH/765/F/1928

${ }^{69}$ Jeanette OH/673/F/1939

${ }^{70}$ Margaret, OH/104/F/1932

${ }^{71}$ Bowlby, Carried Away, 31; see also Davies and Elliott, "The Evolution of the Empowered Consumer"

${ }^{72}$ Margaret, OH/104/F1932 
${ }^{73}$ Jeanette OH/673/F/1939

${ }^{74}$ Shaw et al, "Selling Self-Service"

${ }^{75}$ Jeanette OH/674/F/1940

${ }^{76}$ Humphery, Shelf Life, 75

${ }^{77}$ Jeanette: QR/674/F/1940

${ }^{78}$ see Phillips et al, "Consumer Misbehavior"

${ }^{79}$ Elaine, OH/77/F/1951

${ }^{80}$ McClelland, "The Supermarket and Society", 133; see also Sofer, "Buying and Selling”; JWT, Shopping in Suburbia

${ }^{81}$ For details see Alexander et al, "Innovation and Shopping Practices"; Sofer, "Buying and Selling"

82 JWT, Shopping in Suburbia

${ }^{83}$ Edith $\mathrm{OH} / 566 / \mathrm{F} / 1923$

${ }^{84}$ McClelland, "The Supermarket and Society"

${ }^{85}$ Janet, OH/JT/F/--

${ }^{86}$ McClelland, "The Supermarket and Society", 139

${ }^{87}$ Pauline $\mathrm{OH} / \mathrm{PB} / \mathrm{F} /-$

${ }^{88}$ Mayol, "Propriety" in The Practice of Everyday Life eds. de Certeau, Giard and Mayol

${ }^{89}$ Margaret, WG10/MD//F/1946

${ }^{90}$ Sofer, "Buying and Selling"

${ }^{91}$ See for instance LCS No 2 Subcommittee Reports 3 Sept 1962- 20 Jan 1964

92 Rafaeli, "When Cashiers Meet Customers"

${ }^{93}$ Elaine, OH/77/F/1951

${ }^{94}$ McClelland, "The Supermarket and Society", 137

${ }^{95}$ Anne, WG10/AB/F/1938

${ }^{96}$ Doris, OH/573/F/1935

${ }^{97}$ JWT, The Changing Face of Supermarket Shopping

${ }^{98}$ See also Alexander et al, "Innovation and Shopping Practices"

${ }^{99}$ JWT, Shopping in Suburbia, 27

${ }^{100}$ Alexander et al, "Innovation and Shopping Practices" 
${ }^{101}$ Gill, OH/782/F/1945

${ }^{102}$ See for example Warde, "Consumption and Theories of Practice"; McMeekin and Southerton, "Innovation and Final Consumption"

${ }^{103}$ Gronow and Warde, Ordinary Consumption

${ }^{104}$ Joyce, The New Housewife; Davies and Elliott, "The Evolution of the Empowered Consumer”; Sandbrook, Never Had it So Good, 120

${ }^{105}$ Goldman, "Stages in the Development of the Supermarket"; Alexander, "Format Development"; Shaw and Alexander, "British Co-operative Societies"

${ }^{106}$ Arnould, Price and Malshe, "Toward a cultural resource-based theory" in The Service-Dominant Logic of Marketing eds. Lusch and Vargo

${ }^{107}$ Etgar, “A Descriptive Model”, 100 


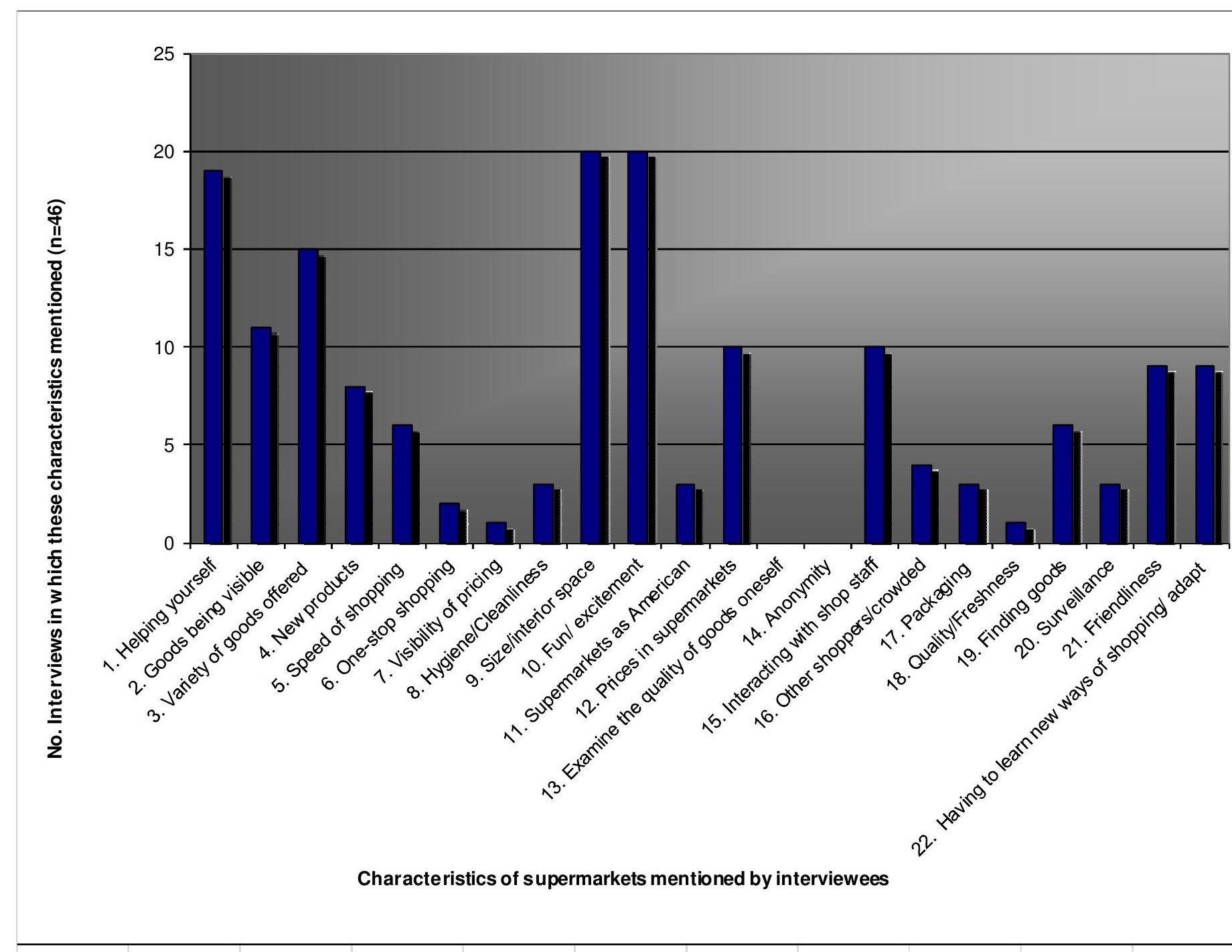

Figure 1 Key themes in interviews discussing first experiences of shopping in a supermarket. 